\title{
CONF-971160--1
}

\section{Cascade Multilevel Inverters for Utility Applications}

\author{
F. Z. Peng, IEEE Senior Member, J. W. McKeever, and D. J. Adams \\ Oak Ridge National Laboratory* \\ P.O. Box 2009, Bldg. 9104-2, MS 8058 \\ Oak Ridge, Tennessee 37831-8058 \\ Phone: 423-576-7261, Fax: 423-241-6124 \\ Email: pengfz@ornl.gov
}

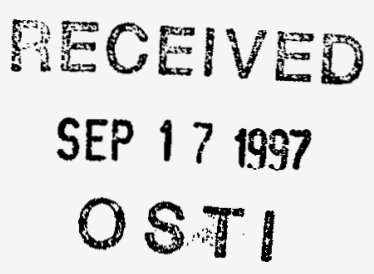

\begin{abstract}
Cascade multilevel inverters have been developed by the authors for utility applications. A cascade $\mathrm{M}$-level inverter consists of $(\mathrm{M}-1) / 2 \mathrm{H}$-bridges in which each bridge has its own separate de source. The new inverter: (1) can generate almost sinusoidal waveform voltage while only switching one time per fundamental cycle, (2) can eliminate transformers of multipulse inverters used in conventional utility interfaces and static var compensators, and (3) makes possible direct parallel or series connection to medium- and high-voltage power systems without any transformers. In other words, the cascade inverter is much more efficient and suitable for utility applications than traditional multipulse and pulse width modulation (PWM) inverters. The authors have experimentally demonstrated the superiority of the new inverter for reactive power (var) and harmonic compensation. This paper will summarize features, feasibility, and control schemes of the cascade inverter for utility applications including utility interface of renewable energy, voltage regulation, var compensation, and harmonic filtering in power systems. Analytical, simulated, and experimental results demonstrate the superiority of the new inverters.
\end{abstract}

\section{INTRODUCTION}

Recently, flexible AC transmission systems (FACTS), custom power, and power quality have been hot topics because of the increasing power demand, the widespread use of non-linear electronic equipment, and the higher power quality requirements of sensitive loads. To maximize power transmission capability and to provide high power quality at the point of common coupling (PCC) of a distribution system, power conditioning, including voltage regulation and reactive power (var)/harmonic compensation, is an indispensably necessary technology.

Traditionally, a multipulse inverter consisting of several voltage-source inverters connected together through zigzagarrangement transformers is used for renewable energy utility interfaces and var compensation [1-7]. These custom-built transformers: (1) are the most expensive equipment in the system; (2) produce about $50 \%$ of the total losses of the system; (3) occupy a large area of real estate, about $40 \%$ of the total system; (4) cause difficulties in control due to dc magnetizing and $\mathrm{dc}$ overvoltage of the inverters resulting from saturation of the transformers [8]; and (5) are prone to failure.

Correspondingly, high switching frequency (about 10 $\mathrm{kHz}$ ) PWM inverters have been used for harmonic compensation [9-12]. However, the high initial and running costs have hindered its practical use in power distribution systems.

The authors have presented and developed cascade multilevel inverters [13-15]. The cascade inverter has less component count and is more suitable for utility applications than other multilevel inverters [16-19]. The cascade M-level inverter consists of $(\mathrm{M}-1) / 2 \mathrm{H}$-bridges in which each bridge has its own separate $\mathrm{dc}$ source. This multilevel inverter generates almost sinusoidal staircase voltage while switching only one time per line cycle, thus eliminating the required bulky transformers of the multipulse inverter based static var compensators (SVCs) and reducing the initial and running costs tremendously compared with the traditional PWM inverter. A prototype of a compensator (10kVA) using an 11level cascade inverter (21-level line-to-line voltage waveform) has been built for var and harmonic compensation. This paper summarizes features, feasibility, and control schemes of the cascade inverter for voltage regulation, var compensation, and harmonic filtering in power systems. Analytical, simulated, and experimental results demonstrate the superiority of the new compensator.

\section{CASCADE MULTILEVEL INVERTERS}

Figs. 1 and 2 show the $\mathrm{Y}$-connected and $\Delta$-connected 11 level cascade inverters, where $L_{C}$ serves as an interface inductor between the inverter and the utility line. As shown

* Prepared by the Oak Ridge National Laboratory, Oak Ridge, Tennessee 37831-8058, managed by Lockheed Martin Energy Research Corp. for the U. S. Department of Energy under contract DE-AC05-960R22464

The submitted manuscript has been authored by a contractor of the U. S. Government under contract No. DE-AC05-96OR22464. Accordingly, the U. S. Government retains a nonexclusive, royalty-free license to publish or reproduce the published form of this contribution, or allow others to do so, for U. S. Government purposes. 


\section{DISCLAIMER}

This report was prepared as an account of work sponsored by an agency of the United States Government. Neither the United States Government nor any agency thereof, nor any of their employees, make any warranty, express or implied, or assumes any legal liability or responsibility for the accuracy, completeness, or usefulness of any information, apparatus, product, or process disclosed, or represents that its use would not infringe privately owned rights. Reference herein to any specific commercial product, process, or service by trade name, trademark, manufacturer, or otherwise does not necessarily constitute or imply its endorsement, recommendation, or favoring by the United States Government or any agency thereof. The views and opinions of authors expressed herein do not necessarily state or reflect those of the United States Government or any agency thereof. 
in the figures, the cascade inverter consists of a series of $\mathrm{H}$ bridge inverter units for each phase. Fig. 3 shows waveforms of the Y-connected cascade inverter. Each H-bridge generates a quasi-square-wave, $\mathrm{P} 1 \sim \mathrm{P} 5$, which sums up to the phase voltage, $v_{C a-n}$, approaching its reference, $v_{C a-n}^{*}$.

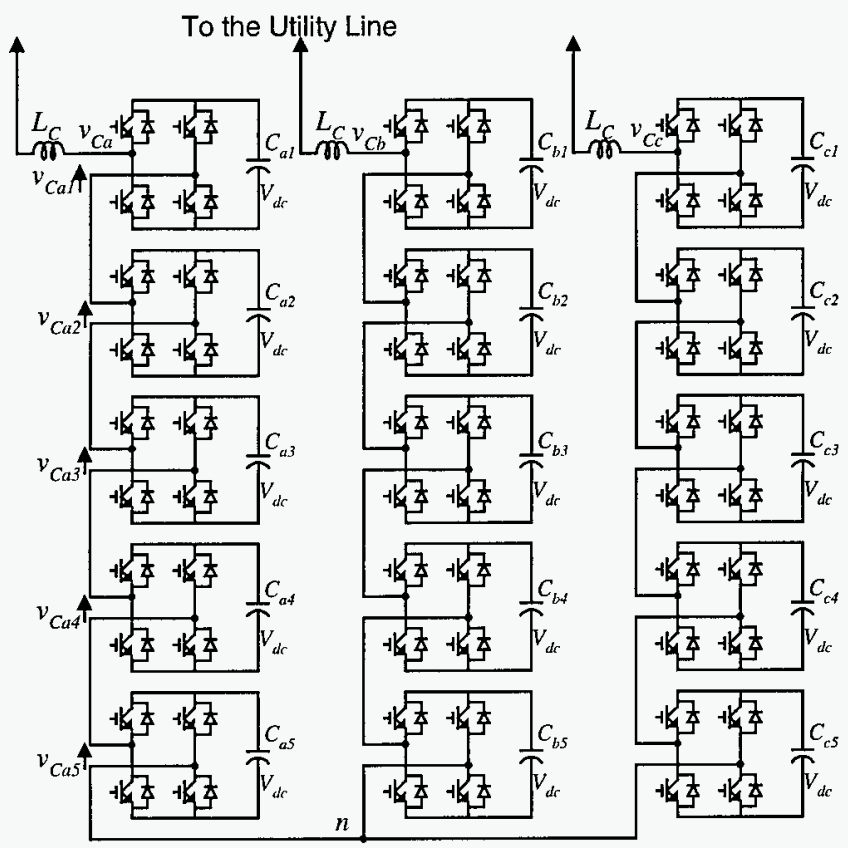

Fig. 1. Three-phase Y-structure of the 11 -level cascade inverter for utility applications.

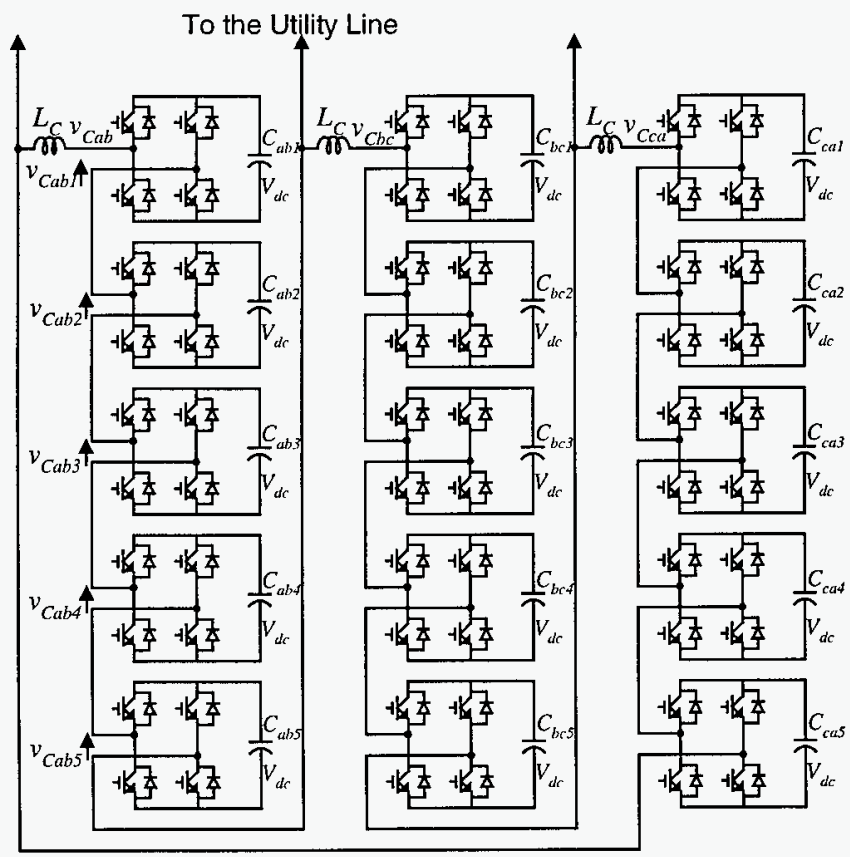

Fig. 2. Three-phase $\Delta$-structure of the 11-level cascade inverter for utility applications.

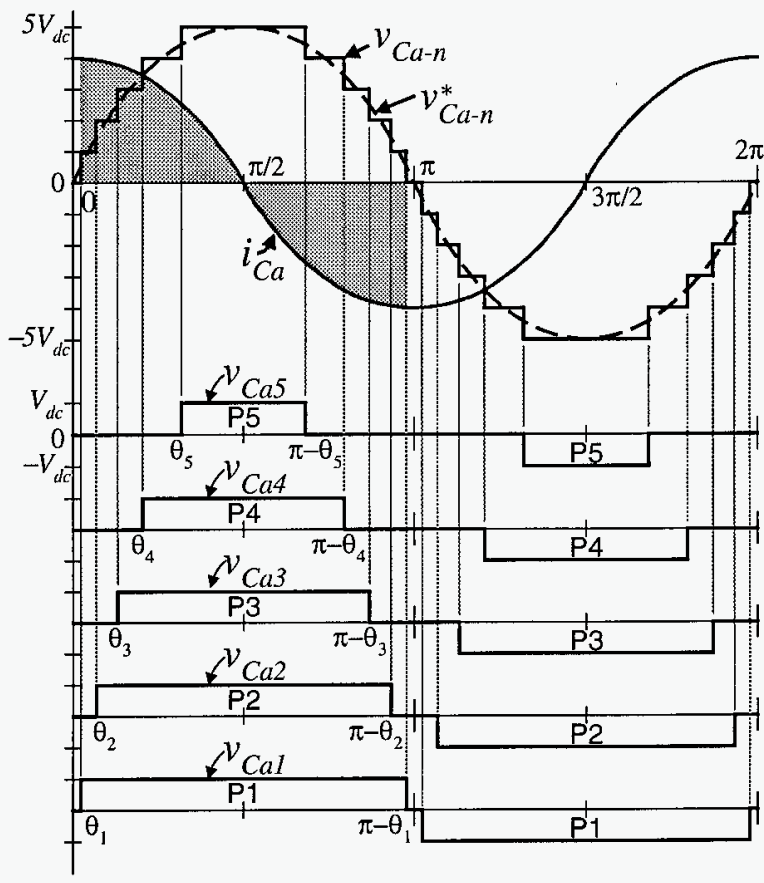

Fig. 3. Waveforms of the 11-level Y-connected cascade inverter.

\section{CASCADE INVERTERS FOR UTILITY APPLICATIONS}

\section{A. Utility Interface of Renewable Energy Sources}

As can be seen in the structure of cascade inverters, each H-bridge needs a separate or isolated dc source. This requirement makes the cascade inverter a perfect fit for utility interface of renewable energy sources such as photovoltaics or fuel cells where isolated dc sources naturally exist. Since the cascade inverter eliminates customer-designed transformers, a tremendous cost reduction can be expected.

\section{B. Voltage Regulation and Phase Shifting}

Fig. 4 shows the system configuration of a cascade inverter for voltage regulation (restoration) and phase shifting. The cascade inverter is coupled in series with the power system and is controlled so that the output voltage, $V_{C}$, is shifted 90 degrees from the line current. In this way, the inverter can provide a stable sine-wave voltage to loads that are sensitive to voltage sags, swings and harmonics, or can provide phase shifting necessary for power flow control.

\section{Reactive Power Control and Compensation}

Fig. 5 shows the system configuration for reactive power control and compensation. The cascade inverter is connected in parallel with the system and can be employed to (1) regulate the terminal voltage, $V_{T}$, and (2) compensate load reactive current through reactive power control. 


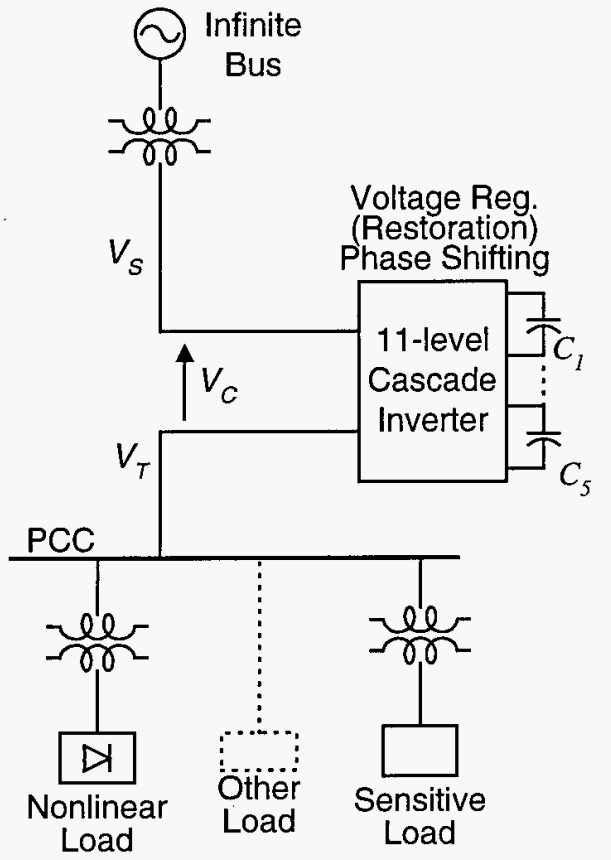

Fig. 4. System configuration for voltage regulation (restoration), phase shifting, and harmonic isolation.

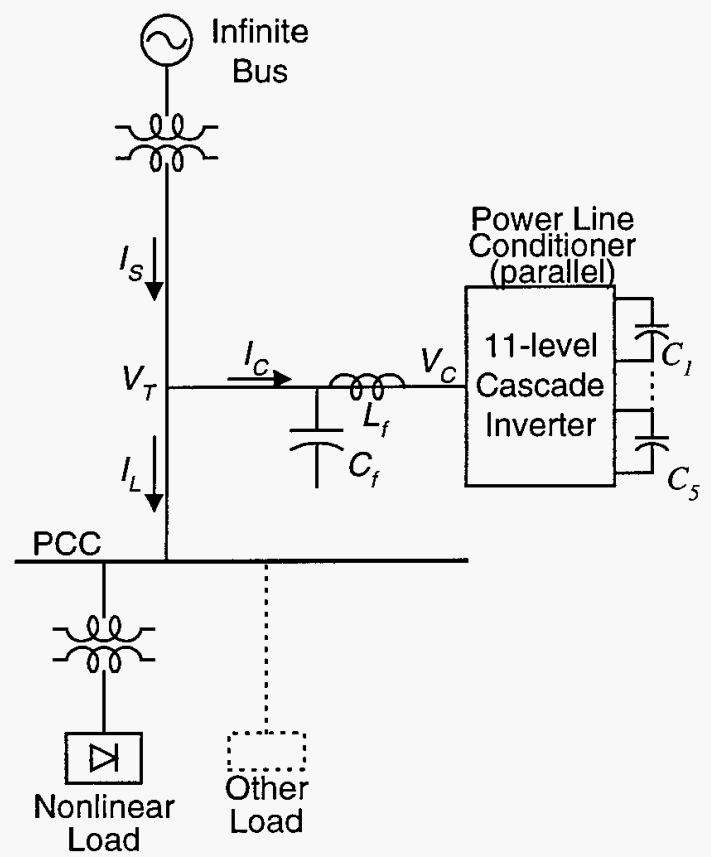

Fig. 5. System configuration for var and harmonic compensation.

\section{Harmonic Filtering}

Both configurations shown in Figs. 4 and 5 can be used for harmonic compensation depending on harmonic source types and compensation objectives [12]. Fig. 4 is the series compensation structure for voltage-source type harmonic sources and can be used for harmonic isolation between the source and the load or between the upstream and the downstream. Correspondingly, Fig. 5 is the parallel compensation structure for current-source type harmonic sources.

\section{CONTROL SCHEMES}

Fig. 3 shows waveforms of the Y-connected 11-level cascade inverter for var compensation. The output phase voltage $v_{C a-n}$ is the sum of five $\mathrm{H}$-bridge inverter units' outputs. The phase voltage magnitude is controlled by each inverter's duty cycle. For var compensation, the phase current, $i_{C u}$, is always leading or lagging the phase voltage $v_{C a-n}$ by 90 degrees. The average charge to each dc capacitor is equal to zero over every half-line cycle for all pulses $\mathrm{P} 1$ to P5. In other words, the voltage of each dc capacitor is always balanced [13,14]. Fig. 6 shows the control block diagram for var compensation only. In the figure, a dc voltage control loop that has an inner loop is included to supplement power losses of the inverter so as to maintain a constant voltage for each dc level.

However, there is voltage-balancing difficulty when the cascade inverter is applied to harmonic filtering. Fig. 7 shows the waveforms, where, for instance, a 5th-harmonic current needs to be absorbed by the inverter. In this case, as shown in the figure, an $\mathrm{H}$-bridge inverter unit will be overcharged if it repeats pulse P5 and over-discharged if it repeats pulse P4. In order to overcome this problem, swapping pulses every half cycle as shown in Fig. 7 is proposed. Fig. 8 shows the control block diagram. As a result, all dc capacitors will be equally charged and balanced. This pulse rotation provides several advantages to the inverter: (1) current ratings will be equalized among the H-bridges and (2) only one dc voltage needs to be monitored and fed-back, thus making control very simple.

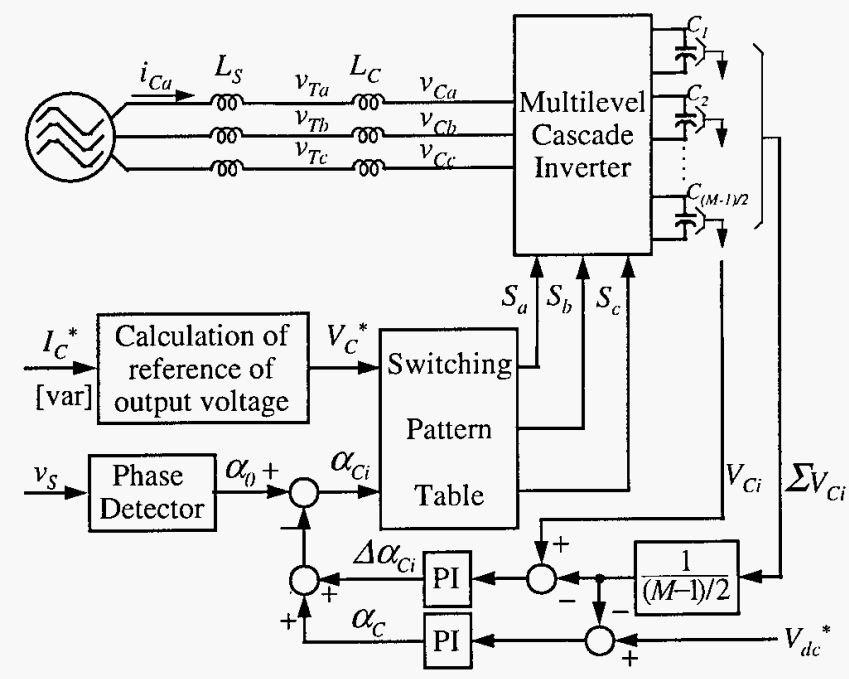

Fig. 6. Control block diagram of the cascade inverter for var compensation. 


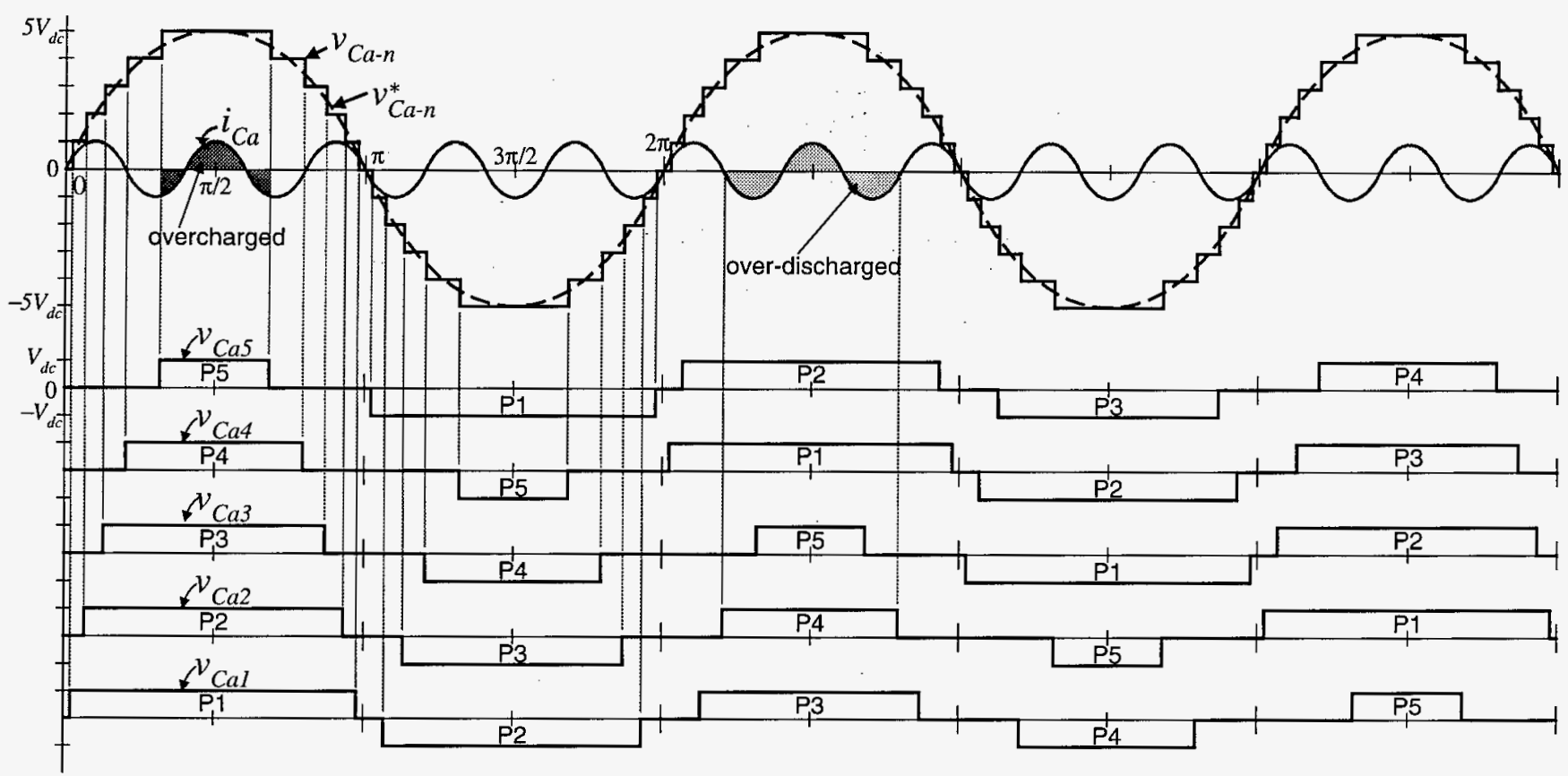

Fig. 7. Waveforms of the cascade inverter for harmonic filtering.

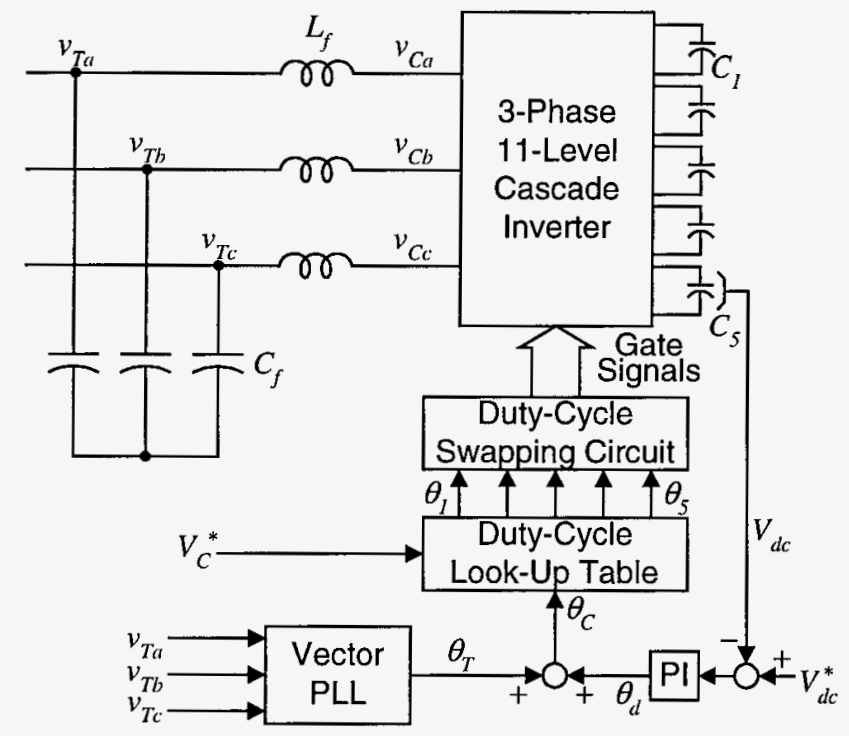

Fig. 8. Control block diagram of the cascade inverter for harmonic and/or var compensation.

As shown in Figs. 6 and 8 , a voltage reference, $V_{C}{ }^{*}$, is needed to control the cascade inverter. Fig. 9 shows a control block diagram of a cascade inverter-based compensator. To compensate for reactive and/or harmonic current, the load current $I_{L}$ is sensed, and its reactive and/or harmonic components are extracted. The current reference, $I_{C}{ }^{*}$, of the compensator can be the load reactive current component, harmonic component, or both depending upon compensation objectives. The cascade inverter has to generate a voltage $V_{C}{ }^{*}$ so that the compensator current $I_{C}$ tracks the current reference $I_{C}{ }^{*} . V_{T}$ is the line voltage, and $K$ is a gain. In a distribution system, the purpose of a power line conditioner is to provide a constant sine voltage to loads, where a constant sine wave is assigned to the voltage reference $V_{C}^{*}$.

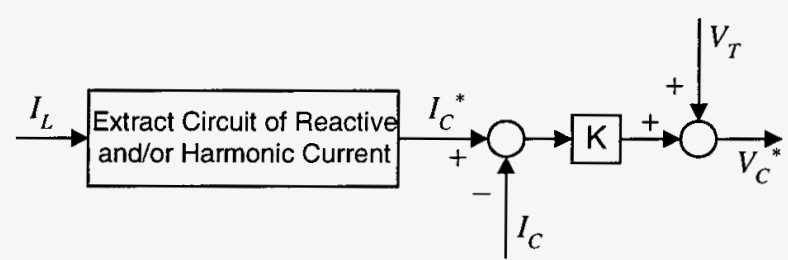

Fig. 9. Control block diagram of cascade inverter-based compensator.

\section{EXPERIMENTAL RESULTS}

Figs. 10 and 11 show some experimental waveforms of the 11-level cascade inverter for var generation/compensation. In this case (Fig. 5), only an interface inductor is connected between the terminal and the inverter. The line-toline output voltage of the inverter is a 21-level staircase approaching the desired sine-wave. The line current is pure sinusoidal. The inverter can generate leading or lagging reactive power as commanded.

Fig. 12 shows a dynamic response of the var compensator. The actual reactive power $q_{C}$ follows the step-change command $q_{C}{ }^{*}$ within $2 \mathrm{~ms}$, quickly enough to cope with the fastest load change in a power system. Figs. 13 and 14 show waveforms for both var and harmonic compensation at PCC. Before the compensator was started, both the terminal voltage, $v_{T a}$, at PCC and source current $i_{S a}$ were distorted due to the nonlinear load. However, both the terminal voltage and source current became sinusoidal and in phase after the compensator was started. 


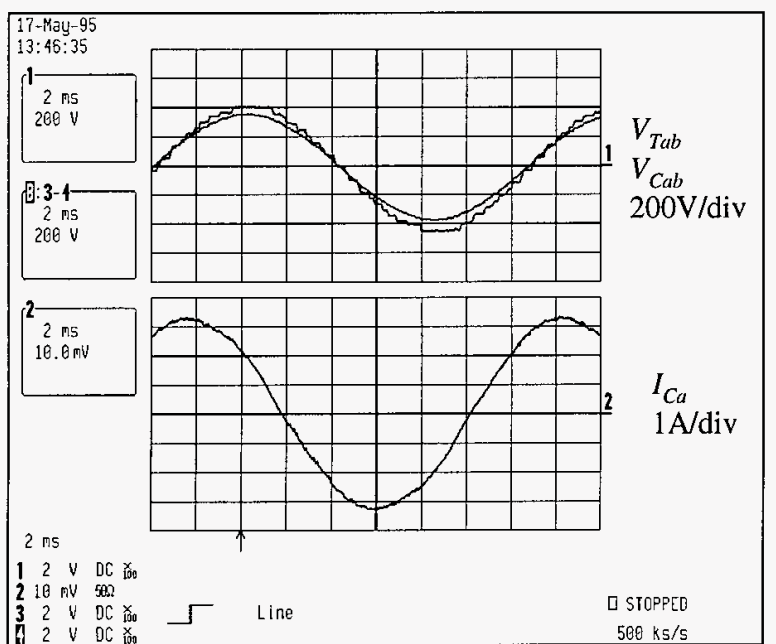

Fig. 10. Experimental results showing line-to-line voltages of the terminal and inverter, $V_{T a b}$ and $V_{C a b}$, and line current, $I_{C a}$, at leading 1 kvar output.

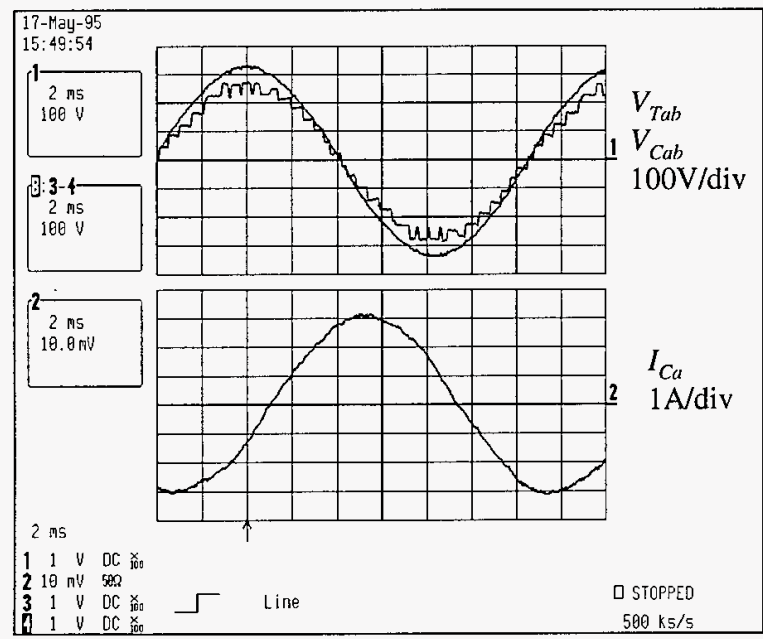

Fig. 11. Experimental results showing line-to-line voltages of the terminal and inverter, $V_{T a b}$ and $V_{C a b}$, and line current, $I_{C l}$, at lagging 1 kvar output.

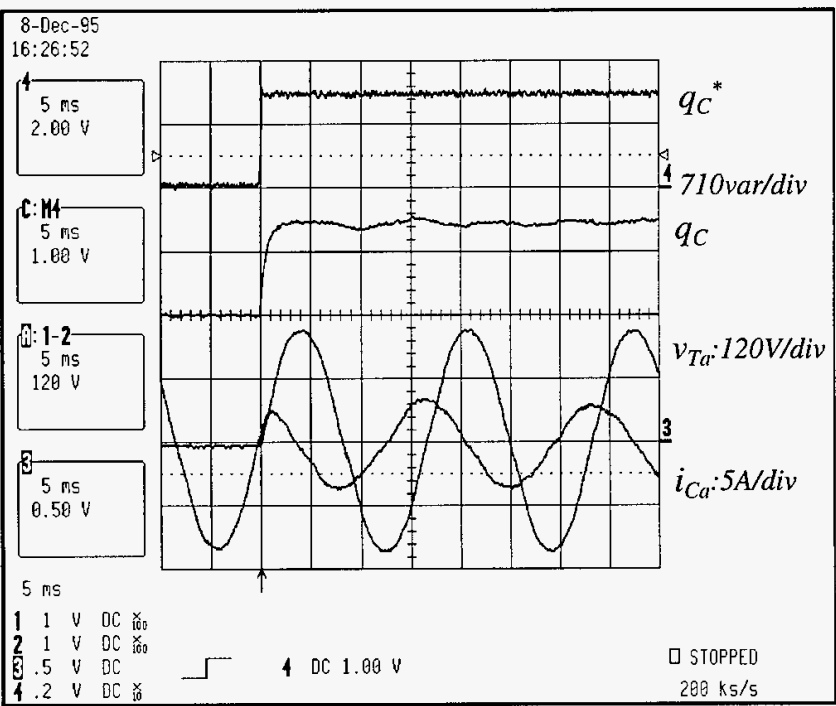

Fig. 12. Experimental waveforms of decoupling feedback control with a step change reference of the reactive current (or reactive power).

\section{CONCLUSIONS}

A new multilevel voltage-source cascade inverter has been presented and developed in Oak Ridge National Laboratory [20] for utility applications. The new inverter has many features, including the least component count, as well as easy modularity and packaging, which solve the major problems of the conventional multipulse inverter, the diode-clamped multi-level inverter, and the flying capacitor multilevel inverter. The cascade inverter is especially suitable for FACTS applications including var/harmonic compensation, series compensation, phase shifting, and voltage balancing because each dc capacitor voltage can be self-maintained and independently controlled without additional dc sources. The superiority and validity have been demonstrated through experimental and simulated results. This cascade inverter topology can be easily adapted to other applications, such as fuel cell and photovoltaic utility interfaces where the sources are naturally isolated dc sources. For these niched applications, the cascade inverter is very promising.

In summary, the new cascade multilevel inverter, (1) can eliminate the bulky transformers of a multipulse inverter, (2) can generate almost sinusoidal waveform voltage and current with only a single switching per fundamental cycle, and (3) has fast dynamic response. In addition, because of its modular and simple structure, the cascade inverter can be stacked up to a practically unlimited number of levels. These features make it the best candidate for medium- to highvoltage power system applications. This paper has summarized its main utility applications and controls. It has been shown that the cascade inverter is suitable for many utility applications. The inverter provides lower costs, higher performance, less EMI, and higher efficiency than the traditional PWM inverter for power line conditioning applications. Simple control schemes have been presented for reactive and harmonic compensation, which ensure dc voltage balance. Future use of Ultra-Capacitors makes the cascade inverter more attractive for wider utility applications.

\section{REFERENCES}

[1] C. Schauder et al., "Development of a \pm 100 MVAR Static Condenser for Voltage Control of Transmission Systems," IEEE PES Summer Power Meeting, San Francisco, CA, July 24-28, 1994, Paper No. 94SM479-6PWRD.

[2] S. Mori et al., "Development of Large Static Var Generator Using Self-Commutated Inverters for Improving Power System Stability," IEEE PES Winter Power Meeting, New York, NY, Jan. 26-30, 1992, Paper No. 92WM165-1.

[3] J. Van Wyk, D. A. Marshall, and S. Boshoff, "Simulation and experimental study of a reactively loaded PWM converter as a fast source of reactive power," IEEE Trans. Ind. Appl., vol. IA-22, no. 6, pp.1082-1090, 1986.

[4] L. H. Walker, "Force-commutated reactive power compensator," IEEE Trans. Ind. Appl., vol.22, no.6, pp.1091-1104, 1986. 


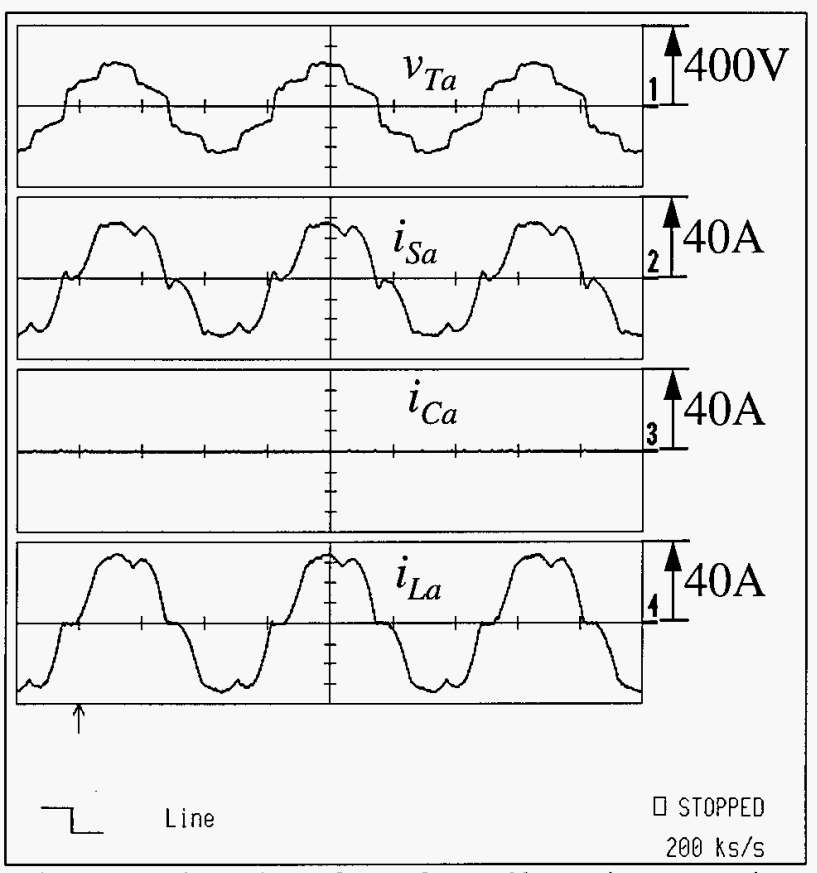

Fig. 13. Experimental waveforms of var and harmonic compensation (before the compensator was started).

[5] H. Fujita, S. Tominaga, and H. Akagi, "Analysis and Design of an Advanced Static Var Compensator Using Quad-Series Voltage-Source Inverters," IEEE/IAS Annual Meeting, pp.2565-2572, Orlando, FL, Oct. 8-12, 1995.

[6] C. D. Schauder, "Advanced Static Var Compensator Control System," U.S. Patent 5,329,221. Jul. 12, 1994.

[7] N. Seki et al., "Which is better at a high power reactive power compensation system, High PWM frequency or multiple connection?" IEEE/IAS'94 Annual Meeting, pp.946-953, Denver, CO, Oct. 2-6, 1994.

[8] A. Nakamori and N. Eguchi, "DC Overvoltage Phenomenon of Multipulse Inverter Transformers for Utility Applications," 1994 National Convention Record IEE of Japan, Paper Number 552, pp. 5-93.

[9] L. Gyugyi and E. C. Strycula, "Active ac power filters," IEEE/IAS Annual Meeting, pp.529-537, 1976

[10] H. Akagi, A. Nabae, and S. Atoh, "Control strategy of active power filters using multiple voltage-source PWM converters," IEEE Trans. Ind. Appl., vol. IA-20, no.3, pp.460-466, 1986.

[11] F. Z. Peng, H. Akagi, and A. Nabae, "A study of active power filters using quad-series voltage-source PWM converters for harmonic compensation," IEEE Trans. on Power Electronics, vol. 5, no.1, pp.9-15, 1990.

[12] F. Z. Peng and J. Lai, "Application considerations and compensation characteristics of shunt active and series active filters in power systems," Proceedings of the 7th International Conference on Harmonics and Quality Power, Las Vegas, NV, pp. 12-20, Oct. 16-18, 1996.

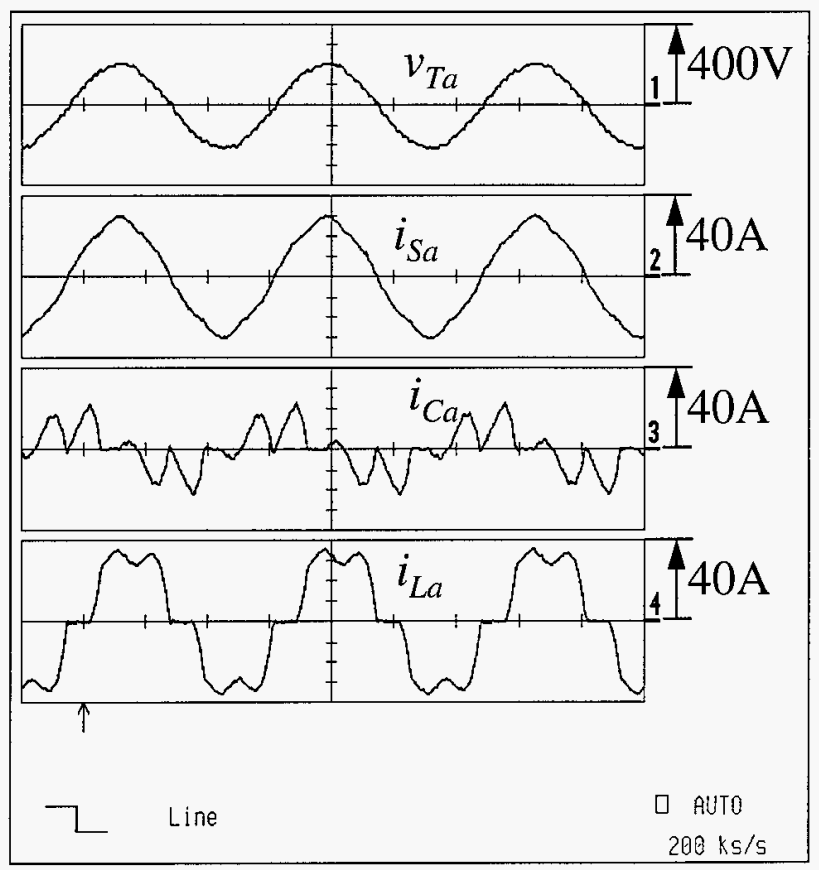

Fig. 14. Experimental waveforms of var and harmonic compensation (after the compensator was started).

[13] F. Z. Peng and J. S. Lai, "A Multilevel Voltage-Source Inverter with Separate DC Sources for Static Var Generation," IEEE/IAS Annual Meeting. pp.2541-2548, Orlando, FL, Oct. 8-12, 1995.

[14] F. Z. Peng and J. S. Lai, "Dynamic performance and control of a static var compensator using cascade multilevel inverters," IEEE/IAS Annual Meeting. pp. 1009-1015, San Diego, CA, Oct. 6-10, 1996.

[15] F. Z. Peng, J. W. McKeever, and D. J. Adams, "A Power Line Conditioner Using Cascade Multilevel Inverters for Distribution Systems," IEEE/IAS Annual Meeting, New Orleans, LA, Oct. 5-9, 1997.

[16] M. Carpita and S. Teconi, "A Novel Multilevel Structure for Voltage Source Inverter," EPE, pp. 90-94, 1991.

[17] T. A. Meynard and H. Foch, "Imbricated Cells Multi-level Voltage-Source Inverters for High Voltage Applications," European Power Electronics Journal, vol. 3, no. 2, pp. 99106, June 1993.

[18] C. Hochgraf, R. Lasseter, D. Divan, and T. A. Lipo, "Comparison of Multilevel Inverters for Static Var Compensation," IEEE/IAS Annual Meeting, pp. 921-928, Denver, CO, Oct. 2-6, 1994.

[19] N. Mohan and D. R. Kamath, "A Novel, High-Frequency, Per-Phase Static Var Compensator," IEEE/IAS Annual Meeting, pp. 2581-2586, Orlando, FL, Oct. 8-12, 1995.

[20] F. Z. Peng and J. S. Lai, "Multilevel Cascade Voltage Source Inverter with Separate DC Sources," U. S. Patent \#5,642,275, June 24, 1997. 


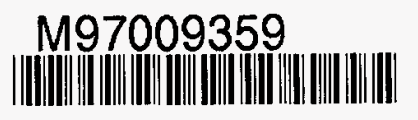

(19) DOE, XF
(9) UE-MD, DOE

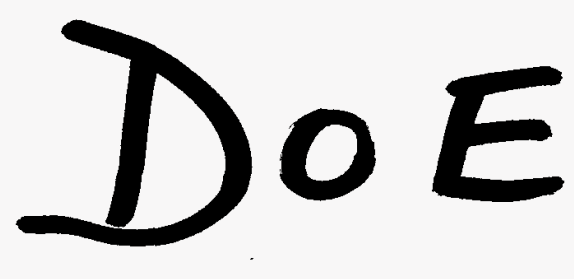

19971202058 